\title{
Efficacy of captopril in postponing nephropathy in normotensive insulin dependent diabetic patients with microalbuminuria
}

\author{
Elisabeth R Mathiesen, Eva Hommel, Jørn Giese, Hans-Henrik Parving
}

\begin{abstract}
Objective-To assess the effectiveness of angiotensin converting enzyme inhibition in preventing the development of diabetic nephropathy (albuminuria $>300 \mathrm{mg} / 24 \mathrm{~h}$ ).

Design-Open randomised controlled study of four years' duration.

Setting-Outpatient diabetic clinic in tertiary referral centre.

Patients -44 normotensive (mean blood pressure $127 / 78$ (SD 12/10) $\mathrm{mm} \mathrm{Hg}$ ) insulin dependent diabetic patients with persistent microalbuminuria (30-300 $\mathrm{mg} / 24 \mathrm{~h}$ ).

Interventions - The treatment group $(\mathrm{n}=\mathbf{2 1})$ was initially given captopril $(25 \mathrm{mg} / 24 \mathrm{~h})$. The dose was increased to $100 \mathrm{mg} / 24 \mathrm{~h}$ during the first 16 months and thiazide was added after 30 months. The remaining 23 patients were left untreated.

Main outcome measures-Albuminuria, kidney function, development of diabetic nephropathy (albuminuria $>300 \mathrm{mg} / 24 \mathrm{~h}$ ), and arterial blood pressure.

Results-Clinical and laboratory variables were comparable at baseline. Urinary excretion of albumin was gradually reduced from $82(66-106)$ to $57(39-85)$ $\mathrm{mg} / 24 \mathrm{~h}$ (geometric mean (95\% confidence interval)) in the captopril treated group, whereas an increase from $105(77-153)$ to $166(83-323) \mathrm{mg} / 24 \mathrm{~h}$ occurred in the control group $(p<0.05)$. Seven of the untreated patients progressed to diabetic nephropathy, whereas none of the captopril treated patients developed clinical overt diabetic nephropathy $(p<0.05)$. Systemic blood pressure, glomerular filtration rate, haemoglobin $A_{1 c}$ concentration, and urinary excretion of sodium and urea remained practically unchanged in the two groups.
\end{abstract}

Conclusions-The findings suggest that angiotensin converting enzyme inhibition postpones the development of clinical overt diabetic nephropathy in normotensive insulin dependent diabetic patients with persistent microalbuminuria.

Hvidøre Hospital, 2930

Klampenborg, Denmark Elisabeth R Mathiesen, MD, research fellow

Eva Hommel, $\mathrm{MD}$, research fellow

Hans-Henrik Parving, MD, chief physician

Department of Clinical Physiology, Glostrup Hospital, Copenhagen, Denmark

Jørn Giese, MD, chief

physician

Correspondence to: Dr Mathiesen.

BMF 1991;303:81-7 failure in patients with diabetic nephropathy. ${ }^{4 \cdot 6}$ During the past decade the prognosis of diabetic nephropathy has improved substantially, probably as a consequence of early and aggressive antihypertensive treatment. ${ }^{78}$ Nevertheless, diabetic nephropathy is still the single most important cause of end stage renal disease in the Western World, accounting for over a quarter of all end stage renal disease in the United States. Thus there is an urgent need to evaluate treatments which may delay or even prevent the development of diabetic nephropathy in the subpopulation at risk.

The insulin dependent diabetes mellitus subpopulation at risk may now be identified fairly accurately by the detection of microalbuminuria. Longitudinal studies have shown that raised urinary albumin excretion below the level of clinical albuminuria - so called microalbuminuria-strongly predicts the development of nephropathy in insulin dependent diabetes. $^{9.12}$ The prevalence of microalbuminuria, defined as urinary albumin excretion between 30 and $300 \mathrm{mg} / 24 \mathrm{~h},{ }^{13}$ was around $20 \%$ in a large diabetic clinic. ${ }^{14}$ is The development and progression of microalbuminuria is associated with poor metabolic control. ${ }^{14-17}$ We have found that near normal blood glucose control achieved with insulin pumps can delay the development of diabetic nephropathy and thus preserve a normal and stable glomerular filtration rate in patients with persistent microalbuminuria. ${ }^{18}$ Unfortunately, severe and even lethal side effectsfor example, hypoglycaemia and ketoacidosis-are reported more often. ${ }^{18-20}$

A small increase in arterial blood pressure is an early and common finding in patients with microalbuminuria. ${ }^{12141621} \mathrm{~A}$ rise in systemic blood pressure transmitted to the glomerular capillary network results in glomerular hypertension, ${ }^{22}$ which has also been shown in most normotensive rats with streptozotocin induced diabetes. ${ }^{23} \mathrm{~A}$ link between raised intraglomerular pressure and albuminuria and the development and progression of diabetic renal disease has been reported..$^{24}$ Acute reduction of systemic blood pressure in normotensive patients with persistent microalbuminuria reduces urinary albumin excretion, ${ }^{26}$ probably owing to a reduction in intraglomerular pressure. In diabetic $W$ istar rats angiotensin converting enzyme inhibition reduces glomerular hypertension, restricts the increase in urinary albumin excretion, and slows the development of glomerular structural lesions. ${ }^{23}$

We report a four year prospective randomised controlled trial aimed at evaluating the effect of angiotensin converting enzyme inhibition on the development of diabetic nephropathy in normotensive insulin dependent diabetic patients with persistent microalbuminuria. Captopril was chosen because it is effective and well tolerated in hypertensive patients with diabetic nephropathy. ${ }^{27}$ 
Patients and methods

We examined the records of all insulin dependent diabetic patients with microalbuminuria $(n=220)$ above the age of 17 visiting the outpatient clinic at Hvidøre hospital in 1985..$^{+21}$ From this population we identified all patients $(n=130)$ aged under 50 whose onset of diabetes was before the age of 41 , whose duration of diabetes was five to 30 years, whose diastolic blood pressure was below $95 \mathrm{~mm} \mathrm{Hg}$, and who had no other disease. These patients were asked to provide three 24 hour urine samples. If urinary albumin excretion in at least two out of three consecutive sterile urine samples collected was in the range $30-300 \mathrm{mg} / 24 \mathrm{~h}$ the patients fulfilled the criteria for persistent microalbuminuria. ${ }^{13}$ Thirty six patients had median values $<30 \mathrm{mg} / 24 \mathrm{~h}$ and 23 patients median values $>300 \mathrm{mg} / 24 \mathrm{~h}$ (that is, diagnostic of nephropathy); 14 patients with persistent microalbuminuria received diuretics or other antihypertensive drugs; and five patients were pregnant or planned to get pregnant. The remaining 52 patients with persistent microalbuminuria were asked to participate in the study and 45 accepted. All had an average of three or more consecutive blood pressure readings below $160 / 95 \mathrm{~mm}$ $\mathrm{Hg}$, a glomerular filtration rate $>90 \mathrm{ml} / \mathrm{min} / 1.73 \mathrm{~m}^{2}$, and otherwise normal findings on urine analysis. All gave informed consent, and the study was approved by the scientific ethics committee of Copenhagen County.

The 45 patients were matched in pairs $(n=22)$ with respect to urinary albumin excretion, blood pressure, haemoglobin $\mathrm{A}_{\mathrm{lc}}$ concentration, and glomerular filtration rate and one of each pair then assigned at random to receive either captopril $(n=22)$ or no blood pressure lowering agent $(n=23)$. Shortly after randomisation one woman (urinary albumin excretion $132 \mathrm{mg} / 24 \mathrm{~h}$ at baseline) in the captopril group was excluded because of abuse of pain relieving tablets for chronic headache. Treatment with captopril was aimed at preventing the expected rise in arterial blood pressure and, if possible, reducing the diastolic blood pressure by $5 \mathrm{~mm} \mathrm{Hg}$. The initial dose was $25 \mathrm{mg} / 24 \mathrm{~h}$, taken as $12.5 \mathrm{mg}$ at 0700 and $12.5 \mathrm{mg}$ at 1800 . The mean diastolic blood pressure was evaluated at six, 12 , and 24 months. If the desired effect was not achieved the dose of captopril was subsequently doubled. The maximum dose was set at $100 \mathrm{mg} / 24 \mathrm{~h}$, and thereafter bendrofluazide could be added. Throughout the study all patients continued with their usual diabetic diet without sodium, protein, or energy restriction. All patients were receiving at least two daily injections of highly purified insulin. Supplementation with potassium chloride accompanied treatment with diuretics during the last six months of the study.

All patients were seen by the same observer (ERM) in the outpatient clinic at $0,1,3,6,9,12,16,20,24$, $28,30,32,34,36,40,44$, and 48 months. Blood pressure was measured on the right arm after 10 minutes' rest in the supine position. A Hawksley random zero device was used and the sounds monitored to the nearest $2 \mathrm{~mm} \mathrm{Hg}$. Diastolic blood pressure was measured at the point of disappearance of the Korotkoff sounds (phase V). At 36 months a 24 hour profile of ambulatory systemic blood pressure was measured by a portable recorder (TM-2420, Takeda Medical, Tokyo). ${ }^{28}$ Systolic and diastolic blood pressure and pulse rate were measured at 15 minute intervals throughout the day and at 30 minute intervals during the night. Mean hourly blood pressure and average blood pressure during the 24 hours were calculated, all measured values being given the same weight. Two patients in each group did not wish to participate in this part of the study.

Two 24 hour urine collections were obtained at each visit. Urinary albumin concentration was measured by radioimmunoassay ${ }^{29}$ in all urine samples. The assay has a sensitivity of $0.5 \mathrm{mg} / \mathrm{l}$ and a coefficient of variation of $9 \%$. The day to day coefficient of variation for 24 hour urinary albumin excretion in individual patients is around $50 \% .^{30}$ The completeness of the urine collection was evaluated by measuring creatinine excretion in each urine sample. Diabetic nephropathy was diagnosed clinically if persistent albuminuria developed in a patient with otherwise normal urine and no clinical or laboratory evidence of kidney or urinary tract disease other than diabetic glomerulosclerosis. At follow up persistent albuminuria was defined as a geometric mean urinary albumin excretion exceeding 300 $\mathrm{mg} / 24 \mathrm{~h}$ based on at least six consecutive urine collections during six months of observation.

Renal clearance studies were performed at 0 time, 6 months, and 1,2,3, and 4 years with the patients supine between 0800 and 1330 . Blood pressure was measured as previously described. Thereafter, patients in the treatment group received their current dose of captopril and diuretics. Patients had their usual breakfast and morning insulin at 0930 and drank $200 \mathrm{ml}$ tap water per hour during the procedures.

Plasma volume was estimated (at 0830) from the rate of disappearance of intravenously injected human serum albumin labelled with iodine-125 (code MIAK Institute of Atomic Energy, Kjeller, Norway).." The glomerular filtration rate and extracellular fluid volume were measured after a single intravenous injection of $3.7 \mathrm{MBq}$ chromium-51 labelled EDTA (at 0900) by determining the radioactivity in venous blood samples taken $5,7,10,15,30,45,60,90,120,150,180,200$, 220 , and 240 minutes after the injection. ${ }^{32}{ }^{33}$ Normal values in normoalbuminuric insulin dependent diabetic patients are glomerular filtration rate 122 (SD 17) $\mathrm{ml} / \mathrm{min} / 1.73 \mathrm{~m}^{2}$ and extracellular fluid volume 13.1 $(0.9) 1 / 1.73 \mathrm{~m}^{2} .{ }^{34}$ Urine was collected during the clearance period for measuring the albumin concentration. Fractional albumin clearance was calculated as albumin clearance divided by the simultaneously measured glomerular filtration rate. If urinary tract infection or appreciable ketonuria was present appropriate treatment was given and the clearance study postponed for two weeks.

Blood glucose concentration was measured hourly during the four hour clearance period by using a reflectance meter (Reflomat; Boehringer-Mannheim, Ingelheim, West Germany). In a few patients supplementation with a $10 \mathrm{~g}$ glucose drink or 2-4 IU neutral insulin injection (Actrapid) intravenously was necessary in order to keep the blood glucose concentration between 4 and $15 \mathrm{mmol} / \mathrm{l}$ during the clearance study. Haemoglobin $A_{1 c}$ concentration (normal range $4 \cdot 1-6 \cdot 1 \%)^{35}$; serum creatinine, electrolyte, albumin, total cholesterol, high density lipoprotein cholesterol, and triglyceride concentrations; and leucocyte count were measured during each investigation by conventional laboratory techniques. Plasma samples for determination of active renin ${ }^{36}$ and angiotensin $\mathrm{I}^{37}$ and angiotensin $\mathrm{II}^{38}$ concentrations were collected at 1000 and after at least one hour in the supine position. These hormones were measured only at 0,6 , and 24 months because of limited capacity. The two 24 hour urine samples collected at $0,6,12,24,36$, and 48 months were analysed for sodium and urea concentrations by conventional techniques. Protein intake was calculated as 6.25 times total urinary nitrogen excretion ( 24 hour urinary urea nitrogen excretion plus non-urea nitrogen excretion estimated to 2 g/day per patient). ${ }^{3940}$ Ophthalmoscopy was carried out on dilated pupils at least every 12 months.

\section{STATISTICAL ANALYSIS}

Results are expressed as means and standard deviation (SD) or range. Values for urinary albumin 
excretion, fractional urinary albumin clearance, and plasma activities of active renin and concentrations of angiotensin I and angiotensin II were logarithmically transformed before analysis of their positively skewed distribution and the geometric means with ranges given. The main results are given with $95 \%$ confidence intervals. Paired and unpaired Student's $t$ tests were used for comparisons within and between the groups.

The best polynomial fit for the time course of urinary albumin excretion, blood pressure, fractional albumin clearance, and glomerular filtration rate was sought with analysis of variance. The best fit was linear in all cases, and the slope of a fitted line to the data was measured by the regression coefficient estimated by least squares. The individual slopes of the two groups were compared by Student's $t$ test. All patient data were included in the analysis. In four patients the last values of blood pressure and urinary albumin excretion before pregnancy or antihypertensive treatment were used.

Because of the logarithmic transformation of data the mean relative changes a year in urinary albumin excretion and fractional albumin clearance were calculated as follows: the antilogarithm of the slope was subtracted by 1 and thereafter timed with $100 \%$. The possible confounding influence of imbalance between the two groups in the four matching factors on urinary albumin excretion at follow up and the annual change in urinary albumin excretion was tested by analysis of covariance. Correlations were calculated with stepwise multiple linear regression analysis. A p value of $<0.05$ was considered significant (two tailed).

A prestudy calculation of the required sample size and observation period was performed, based on the following assumptions: an expected increase in diastolic blood pressure and urinary albumin excretion of $4 \mathrm{~mm}$ $\mathrm{Hg}$ and $30 \%$ a year respectively in the control group and $0 \mathrm{~mm} \mathrm{Hg}$ and $10 \%$ a year in the captopril treated group; and inclusion of all eligible patients from the clinic. With $\alpha$ set to $0 \cdot 05, \beta$ set to $0 \cdot 10$, and 21 patients in each group the required observation period was two years.

\section{Results}

The baseline values in the two groups are given in tables I and II. Baseline diastolic blood pressure was below $90 \mathrm{~mm} \mathrm{Hg}$ in all but one patient in each group. The initial dose of captopril $(25 \mathrm{mg} / 24 \mathrm{~h})$ was doubled at nine and 16 months and thereafter kept constant at $100 \mathrm{mg} / 24 \mathrm{~h}$. After 30 months $2.5 \mathrm{mg}$ bendrofluazide was added in the treatment group (fig 1). After 24 months seven patients deviated from the protocol. Owing to oedema formation one patient in the control group (case 20) and two patients in the captopril group (cases 27 and 30) had treatment initiated with frusemide $(80-160 \mathrm{mg} / 24 \mathrm{~h}$ ); one patient in the control group (case

TABLE I-Clinical and laboratory data at baseline in normotensive insulin dependent diabetic patients with persistent microalbuminuria. Except where stated otherwise figures are means (SD in parentheses) or geometric means (ranges in parentheses)

\begin{tabular}{lcc}
\hline & $\begin{array}{c}\text { Control } \\
\text { group }\end{array}$ & $\begin{array}{c}\text { Captopril } \\
\text { group }\end{array}$ \\
\hline No of patients $(\mathrm{F} / \mathrm{M})$ & $23(12 / 11)$ & $21(10 / 11)$ \\
Age $($ years $)$ & $27(8)$ & $31(8)$ \\
Duration of diabetes $($ years $)$ & $17(5)$ & $19(7)$ \\
Fractional albumin clearance & $11 \cdot 4(0 \cdot 9-67)$ & $8 \cdot 8(2 \cdot 4-72)$ \\
$\quad\left(\times 10^{\circ}\right)$ & $129(18)$ & $126(24)$ \\
Glomerular filtration rate $(\mathrm{ml} / \mathrm{min})$ & $8 \cdot 3(1 \cdot 4)$ & $8 \cdot 4(1 \cdot 4)$ \\
Haemoglobin $\mathrm{A}_{\mathrm{Ic}}(\%)$ & $0 \cdot 63(0 \cdot 21)$ & $0 \cdot 66(0 \cdot 15)$ \\
Insulin dose $(\mathrm{IU} / \mathrm{kg} / 24 \mathrm{~h})$ & $7 \cdot 8(2 \cdot 0)$ & $7 \cdot 4(1 \cdot 9)$ \\
Energy intake $(\mathrm{M} / 24 \mathrm{~h})$ & $79(19)$ & $76(23)$ \\
Protein intake $(\mathrm{g} / 24 \mathrm{~h})$ & $23 \cdot 7(2 \cdot 4)$ & $22 \cdot 9(2 \cdot 1)$ \\
Body mass index $\left(\mathrm{kg} / \mathrm{m}^{2}\right)$ & $194(79)$ & $174(58)$ \\
Urinary sodium excretion $(\mathrm{mmol} / 24 \mathrm{~h})$ & $0 / 20 / 3$ & $3 / 15 / 3$ \\
No with retinopathy $($ none/background & & \\
proliferative $)$ & & \\
\hline
\end{tabular}

TABLE II - Initial and four year follow up values of urinary albumin excretion and arterial blood pressure in captopril and control groups. Individual values are means of at least two measurements

\begin{tabular}{|c|c|c|c|c|}
\hline \multirow{2}{*}{$\begin{array}{l}\text { Case } \\
\text { No }\end{array}$} & \multicolumn{2}{|c|}{$\begin{array}{l}\text { Urinary albumin excretion } \\
(\mathrm{mg} / 24 \mathrm{~h})\end{array}$} & \multicolumn{2}{|c|}{ Blood pressure $(\mathrm{mm} \mathrm{Hg})$} \\
\hline & Baseline & Four year follow up & Baseline & Four year follow up \\
\hline \multicolumn{5}{|c|}{ Control group } \\
\hline 1 & 141 & 298 & $134 / 80$ & $143 / 92$ \\
\hline 2 & 236 & 176 & $130 / 81$ & $129 / 85$ \\
\hline 3 & 68 & 87 & $123 / 71$ & $126 / 77$ \\
\hline $4^{\star}$ & 133 & $1949 \ddagger$ & $122 / 82$ & $151 / 105$ \\
\hline 5 & 130 & 140 & $104 / 66$ & $106 / 67$ \\
\hline 6 & 165 & 277 & $127 / 86$ & $129 / 87$ \\
\hline 7 & 54 & $2119 \ddagger$ & $125 / 81$ & $148 / 98$ \\
\hline 8 & 73 & 32 & $136 / 89$ & $128 / 78$ \\
\hline 9 & 64 & 112 & $127 / 72$ & $114 / 77$ \\
\hline 10 & 169 & 61 & $125 / 68$ & $116 / 75$ \\
\hline 11 & 32 & 41 & $115 / 71$ & $142 / 72$ \\
\hline 12 & 100 & 108 & $155 / 93$ & $128 / 70$ \\
\hline 13 & 144 & 88 & $133 / 78$ & $121 / 61$ \\
\hline 14 & 117 & $4164 \ddagger$ & $121 / 80$ & $142 / 89$ \\
\hline 15 & 71 & 30 & $128 / 87$ & $123 / 88$ \\
\hline $16+$ & 190 & 64 & $112 / 70$ & $108 / 56$ \\
\hline 17 & 57 & 123 & $127 / 80$ & $115 / 65$ \\
\hline 18 & 34 & 13 & $120 / 62$ & $110 / 59$ \\
\hline 19 & 282 & $343 \ddagger$ & $117 / 79$ & $116 / 75$ \\
\hline $20 \dagger$ & 168 & $735 \ddagger$ & $117 / 77$ & $118 / 79$ \\
\hline 21 & 165 & $470 \ddagger$ & $123 / 71$ & $113 / 67$ \\
\hline 22 & 137 & $920 \ddagger$ & $129 / 67$ & $120 / 65$ \\
\hline 23 & 34 & 13 & $120 / 80$ & $122 / 67$ \\
\hline $\begin{array}{c}\text { Geometric } \\
\text { mean }\end{array}$ & 105 & 166 & $125 / 77$ & $125 / 76$ \\
\hline \multicolumn{5}{|c|}{ Captopril group } \\
\hline 24 & 68 & 45 & $112 / 69$ & $109 / 65$ \\
\hline 25 & 78 & 21 & $117 / 78$ & $107 / 69$ \\
\hline 26 & 90 & 105 & $123 / 82$ & $106 / 79$ \\
\hline 27 & 204 & 40 & $125 / 87$ & $120 / 75$ \\
\hline 28 & 197 & 90 & $152 / 83$ & $121 / 61$ \\
\hline 29 & 159 & 57 & $132 / 85$ & $122 / 81$ \\
\hline 30 & 54 & 235 & $134 / 75$ & $129 / 80$ \\
\hline 31 & 174 & 63 & $126 / 73$ & $123 / 81$ \\
\hline 32 & 66 & 27 & $122 / 80$ & $109 / 69$ \\
\hline 33 & 46 & 146 & $146 / 72$ & $164 / 72$ \\
\hline 34 & 89 & 269 & $120 / 81$ & $129 / 78$ \\
\hline 35 & 67 & 145 & $120 / 63$ & $111 / 63$ \\
\hline 36 & 81 & 59 & $151 / 91$ & $151 / 78$ \\
\hline 37 & 197 & 37 & $127 / 84$ & $118 / 71$ \\
\hline 38 & 48 & 21 & $117 / 76$ & $116 / 66$ \\
\hline 39 & 77 & 25 & $126 / 71$ & $115 / 76$ \\
\hline 40 & 100 & 87 & $131 / 87$ & $127 / 80$ \\
\hline 41 & 33 & 78 & $141 / 88$ & $160 / 87$ \\
\hline 42 & 54 & 30 & $130 / 87$ & $117 / 70$ \\
\hline $43 \dagger$ & 60 & 9 & $118 / 70$ & $100 / 50$ \\
\hline 44 & 70 & 96 & $123 / 72$ & $114 / 71$ \\
\hline $\begin{array}{c}\text { Geometric } \\
\text { mean }\end{array}$ & 82 & 57 & $128 / 78$ & $122 / 73$ \\
\hline
\end{tabular}

^Last values before antihypertensive treatment.

†Last values before pregnancy.

‡Clinical nephropathy present, with mean urinary albumin excretion exceeding $300 \mathrm{mg} / 24 \mathrm{~h}$ based on six consecutive urine collections during six months of observation.

4) developed hypertension (World Health Organisation criterion; blood pressure $>160 / 95 \mathrm{~mm} \mathrm{Hg}$ ) and began treatment with frusemide $(160 \mathrm{mg} / 24 \mathrm{~h})$; and three patients (cases 16, 20, and 43) became pregnant. During pregnancy and lactation captopril was discontinued.

Urinary excretion of albumin was gradually reduced from 82 (66 to 106) to 57 ( 39 to 85 ) $\mathrm{mg} / 24 \mathrm{~h}$ (geometric mean $(95 \%$ confidence interval)) in the captopril treated group whereas an increase from 105 (77 to 153) to 166 ( 83 to 323$) \mathrm{mg} / 24 \mathrm{~h}$ occurred in the control group $(p<0.05)$. After 16 months urinary albumin excretion was persistently lower in the captopril treated group than in the controls $(\mathrm{p}<0.05$; fig 1$)$. From the 24th month the change in urinary albumin excretion from baseline was persistently lower in the captopril group than in the controls $(p<0 \cdot 05)$. Table III compares the mean annual changes in urinary albumin excretion, fractional urinary albumin clearance, blood pressure, and glomerular filtration rate between the two groups. Urinary albumin excretion and fractional albumin clearance had fallen by an average of $9 \%$ and $16 \%$ a year over the four years in the captopril treated group whereas rises of $8 \%$ and $6 \%$ a year were found in 
the controls. Arterial blood pressure measured as usually performed in a clinical setting remained constant throughout the four years, with no difference between the groups (fig 1; table III). The annual decline in the glomerular filtration rate in the captopril and control groups was small $(1.4$ and $0.6 \mathrm{ml} / \mathrm{min})$, with no differences between the groups (table III).

Seven of the untreated patients had progressed to diabetic nephropathy compared with none of the captopril treated group $(p<0.05$; table II $)$. Of the seven patients developing nephropathy, one had had a baseline urinary albumin excretion value below 60 $\mathrm{mg} / 24 \mathrm{~h}$, three baseline values of $60-150 \mathrm{mg} / 24 \mathrm{~h}$, and three baseline values above $150 \mathrm{mg} / 24 \mathrm{~h}$ (table II). In these seven patients the mean increase in urinary albumin excretion was $27 \%$ a year $(-3 \%$ to $57 \%(95 \%$ confidence interval)). The mean rate of decline in their glomerular filtration rate was $4 \cdot 0(-1$ to 9$) \mathrm{ml} / \mathrm{min}$ a year $(\mathrm{p}=0.08)$ and their mean increase in blood pressure $2(-1$ to 5$) / 1$ ( -1 to 3$) \mathrm{mm} \mathrm{Hg}$ a year. Two of
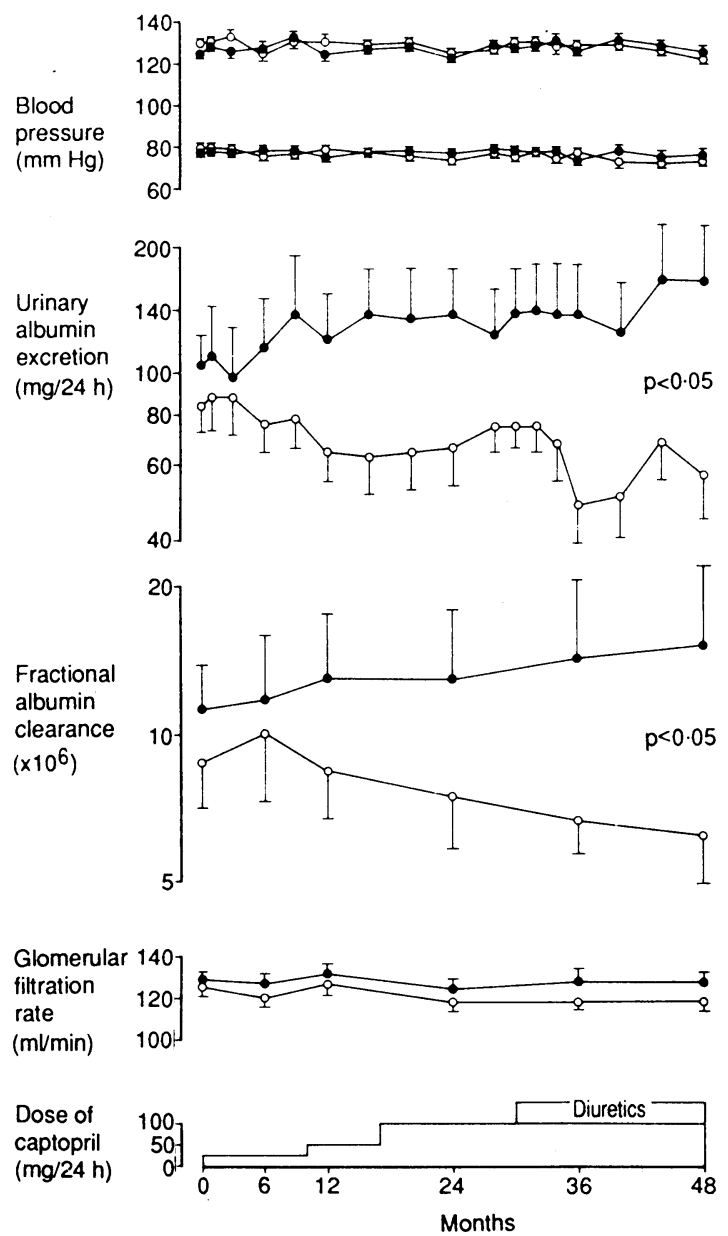

FIG 1 -Time course of mean arterial blood pressure, urinary albumin excretion, fractional albumin clearance, and glomerular filtration rate in normotensive insulin dependent diabetic patients with microalbuminuria. Twenty one patients received captopril $(\mathrm{O})$ and 23 served as untreated controls (). Ordinates of urinary albumin excretion and fractional albumin clearance are log scales. Bars are $S E M$

TABLE III-Annual changes in urinary albumin excretion, fractional urinary albumin clearance, arterial blood pressure, and glomerular filtration rate within and between captopril and control groups. Figures are means ( $95 \%$ confidence intervals)

\begin{tabular}{|c|c|c|c|}
\hline & $\begin{array}{l}\text { Captopril } \\
\text { group }\end{array}$ & $\begin{array}{l}\text { Control } \\
\text { group }\end{array}$ & $\begin{array}{l}\text { Group } \\
\text { difference }\end{array}$ \\
\hline $\begin{array}{l}\text { Urinary albumin excretion (\% relative change) } \\
\text { Fractional urinary albumin clearance }(\% \text { relative change }) \\
\text { Systolic blood pressure }(\mathrm{mm} \mathrm{Hg}) \\
\text { Diastolic blood pressure }(\mathrm{mm} \mathrm{Hg}) \\
\text { Glomerular filtration rate }(\mathrm{m} / \mathrm{min})\end{array}$ & $\begin{array}{l}-9(-18 \text { to } 1) \\
-16(-30 \text { to } 2) \\
-0 \cdot 4(-1 \text { to } 1) \\
-1 \cdot 0(-2 \text { to } 0) \\
-1 \cdot 4(-2 \text { to } 0)\end{array}$ & $\begin{array}{r}8(-2 \text { to } 20) \\
6(-6 \text { to } 19) \\
-0 \cdot 3(-1 \text { to } 1) \\
-0 \cdot 7(-2 \text { to } 0) \\
-0 \cdot 6(-3 \text { to } 1)\end{array}$ & $\begin{array}{r}18(3 \text { to } 32)^{\star} \\
22(1 \text { to } 44)^{\star} \\
0 \cdot 1(-1 \text { to } 2) \\
-0 \cdot 2(-1 \text { to } 1) \\
0 \cdot 8(-1 \text { to } 3)\end{array}$ \\
\hline
\end{tabular}

Captopril group $v$ controls: ${ }^{\star} \mathrm{p}<0 \cdot 05$.
TABLE IV-Plasma values of active renin, angiotensin $I$, and angiotensin II in normotensive insulin dependent diabetic patients with microalbuminuria receiving captopril or no hypotensive treatment. Figures are geometric means (ranges)

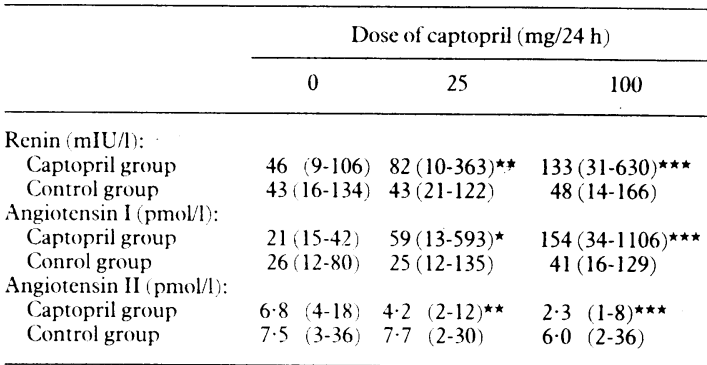

Captopril group $v^{\prime}$ controls: ${ }^{\star} \mathrm{p}<0 \cdot 05,{ }^{\star \star} \mathrm{p}<0 \cdot 01,{ }^{\star \star \star} \mathrm{p}<0 \cdot 001$.

these patients had a substantial decline in their glomerular filtration rate ( 5 and $15 \mathrm{ml} / \mathrm{min}$ a year). In the captopril treated group no patient had a substantial decline in the glomerular filtration rate.

The renin-angiotensin system showed a suppressed plasma concentration of angiotensin II and increased values of angiotensin $I$ and renin in the captopril treated group, indicating substantial inhibition of angiotensin converting enzyme activity (table IV). Metabolic control and urinary excretion of urea did not differ between the two groups at any time during the study (fig 2). No significant changes were observed in the body weight, plasma volume, extracellular fluid volume, serum lipid concentrations, or leucocyte count (table V). Serum potassium concentration and urinary excretion of sodium remained constant during captopril treatment, with a minor decline after diuretics were added.

During treatment with both captopril and thiazide the ambulatory 24 hour blood pressure profiles showed significantly lower diastolic pressure at 0900 and between 1900 and 2300. At 2100, 2300, and 0100 the systolic blood pressure was significantly lower. At other times no significant differences could be detected in systolic or diastolic blood pressure (fig 3). From the total area below the curve the average blood pressure during the 24 hours may be calculated. The mean of 24 hour average blood pressures was 124/71 (SD 14/5) $\mathrm{mm} \mathrm{Hg}$ during treatment. Neither systolic nor diastolic blood pressure differed significantly from the values in the untreated patients (mean 127/75 (13/8) $\mathrm{mm} \mathrm{Hg}$ ).

The individual values of urinary albumin excretion and blood pressure (measured as usually performed in a clinical setting) at baseline and follow up are given in table II. The significant difference between the two groups in urinary albumin excretion at follow up and in the annual change in urinary albumin excretion (table
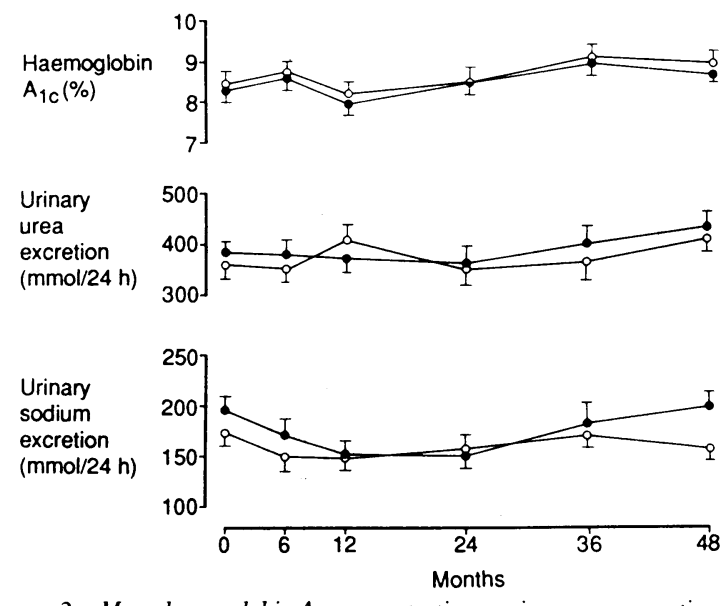

FIG 2-Mean haemoglobin $A_{1 c}$ concentrations, urinary urea excretion, and urinary sodium excretion in normotensive insulin dependent diabetic patients with microalbuminuria. Twenty one patients received captopril $(\bigcirc)$ and 23 served as untreated controls $(\mathbf{O})$. Bars are SEM 


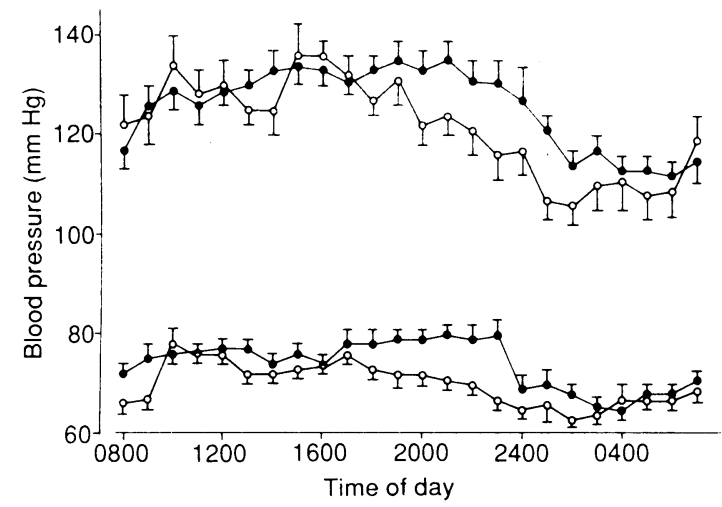

FIG 3-Mean 24 hour blood pressure profiles in normotensive insulin dependent diabetic patients with microalbuminuria (19 patients given captopril and thiazide $(\bigcirc), 21$ untreated controls $(\mathbf{O})$ ). Bars are $S E M$

TABLE V-Initial and four year follow up values in normotensive insulin dependent diabetic patients with microalbuminuria receiving captopril or no hypotensive treatment. Figures are means $(S D)$

\begin{tabular}{|c|c|c|}
\hline & Baseline & $\begin{array}{l}\text { Four year } \\
\text { follow up }\end{array}$ \\
\hline \multicolumn{3}{|l|}{ Body weight $(\mathrm{kg})$ : } \\
\hline Captopril group & $67 \cdot 5(9)$ & $66 \cdot 7$ (9) \\
\hline Control group & 68.9 (11) & $69 \cdot 8(12)$ \\
\hline \multicolumn{3}{|c|}{ Extracellular fluid volume $\left(\mathrm{V} / 1.73 \mathrm{~m}^{2}\right)$ : } \\
\hline Captopril group & $14 \cdot 5 \quad(2 \cdot 4)$ & $14 \cdot 3(2 \cdot 1)$ \\
\hline Control group & $14 \cdot 0(2 \cdot 0)$ & $14 \cdot 3(2 \cdot 8)$ \\
\hline \multicolumn{3}{|c|}{ Plasma volume $\left(1 / 1.73 \mathrm{~m}^{2}\right)$ : } \\
\hline Captopril group & $2 \cdot 75(0 \cdot 5)$ & $2 \cdot 86(0 \cdot 4)$ \\
\hline Control group & $2 \cdot 77(0 \cdot 4)$ & $2 \cdot 81(0.5)$ \\
\hline \multicolumn{3}{|c|}{ Serum potassium $(\mathrm{mmol} / \mathrm{l})$ : } \\
\hline Captopril group & $4 \cdot 1 \quad(0 \cdot 3)$ & $3.8(0.5)$ \\
\hline Control group & $4 \cdot 0 \quad(0 \cdot 4)$ & $3.9(0.3)$ \\
\hline \multicolumn{3}{|c|}{ Leucocyte count $\left(\times 10^{\circ} / 1\right)$ : } \\
\hline Captopril group & $8 \cdot 4(2)$ & $7 \cdot 1 \quad(2)$ \\
\hline Control group & $7 \cdot 4(2)$ & $6 \cdot 6(2)$ \\
\hline \multicolumn{3}{|c|}{ Serum total cholesterol $(\mathrm{mmol} / \mathrm{l})$ : } \\
\hline Captopril group & $5 \cdot 06(1 \cdot 1)$ & $5 \cdot 03(1 \cdot 1)$ \\
\hline Control group & $5 \cdot 11(1 \cdot 3)$ & $5.01(0.9)$ \\
\hline \multicolumn{3}{|c|}{ High density lipoprotein cholesterol $(\mathrm{mmol} / \mathrm{l})$ : } \\
\hline Captopril group & $1 \cdot 30(0 \cdot 3)$ & $1 \cdot 47(0 \cdot 3)$ \\
\hline Control group & $1 \cdot 36(0 \cdot 6)$ & $1.33(0.4)$ \\
\hline \multicolumn{3}{|c|}{ Serum triglyceride $(\mathrm{mmol} / \mathrm{l})$ : } \\
\hline Captopril group & $0 \cdot 97(0 \cdot 2)$ & $0.84(0.5)$ \\
\hline Control group & $1.25(0 \cdot 7)$ & $1.25(0 \cdot 8)$ \\
\hline
\end{tabular}

III) persisted $(\mathrm{p}<0.01, \mathrm{p}<0.05)$ when the possible confounding influence of imbalance in baseline values of urinary albumin excretion, diastolic blood pressure, haemoglobin $A_{1 c}$ concentration, and glomerular filtration rate was tested by analysis of covariance. The change in urinary albumin excretion in the control group was correlated with the change in mean blood pressure during the study but not with baseline urinary albumin excretion, baseline blood pressure, baseline glomerular filtration rate, or mean haemoglobin $A_{1 c}$ concentration during the study. There was no correlation between the change in glomerular filtration rate and baseline urinary albumin excretion, change in urinary albumin excretion, baseline blood pressure, mean blood pressure, or mean haemoglobin $\mathrm{A}_{1 \mathrm{c}}$ concentration during follow up. No side effects occurred, and all 21 patients in the treatment group were continuing with captopril and diuretics.

\section{Discussion}

In this four year prospective randomised controlled study of normotensive insulin dependent diabetic patients with persistent microalbuminuria angiotensin converting enzyme inhibition with captopril reduced urinary albumin excretion while leaving systemic blood pressure and the glomerular filtration rate essentially unchanged. More important, progression to diabetic nephropathy was prevented in the treatment group whereas seven out of 23 control patients progressed to nephropathy with an annual decline in the glomerular filtration rate of $4 \mathrm{ml} / \mathrm{min}$. These results were obtained despite failure to achieve our treatment goal. We strived to obtain a reduction in diastolic blood pressure by increasing the dose of captopril to 100 $\mathrm{mg} / 24 \mathrm{~h}$ and adding a diuretic, but did not succeed.

Our results confirm and extend those of Marre $e t$ al. ${ }^{41}$ They found that enalapril $(20 \mathrm{mg} /$ day $)$ for one year induced a progressive reduction in urinary albumin excretion in 10 normotensive diabetic patients with persistent microalbuminuria. Three of the 10 untreated diabetics developed persistent albuminuria. Both insulin dependent and non-insulin dependent diabetic patients were enrolled in that study.

The reduction in urinary albumin excretion observed in our series was not caused by a decrease in the glomerular filtration rate or serum albumin concentration as the changes in fractional albumin clearance were proportional to the fall in urinary albumin excretion. Several studies have shown that tubular protein reabsorption - as estimated, for example, with $\beta_{2}$ microglobulin - is normal in patients with microalbuminuria. ${ }^{1242}$ We emphasise that haemoglobin $A_{1 c}$ concentration, serum cholesterol and triglyceride concentrations, protein intake, urinary sodium excretion, and body weight remained nearly identical in the two groups during the four years. Energy, sodium, and protein restriction was not applied in our study. Treatment with prostaglandin inhibitors was avoided. Analysis of covariance showed that the imbalance in the four matching factors at baseline did not affect the observed differences in urinary albumin excretion between the two groups. Thus we can rule out these confounding factors. ${ }^{18434}$

Though systemic blood pressure was unchanged both during angiotensin converting enzyme inhibition and after the addition of diuretics in our study, Marre et al found a significant drop. ${ }^{41}$ This disparity may well be explained by the higher systemic blood pressure at baseline and the lower urinary sodium excretion in the study of Marre et al. We measured blood pressure at least six hours after the last antihypertensive dose. The possibility that blood pressure might have been depressed during the remainder of the day was excluded by the ambulatory 24 hour profiles.

The significant effect on urinary albumin excretion was shown with angiotensin converting enzyme inhibition alone. Adding diuretics in the captopril group possibly reduced 24 hour urinary albumin excretion a little further (NS), but a longer observation period will be necessary before the clinical relevance of adding diuretics can be evaluated.

\section{MECHANISMS OF ANTIPROTEINURIC EFFECT}

The observed antiproteinuric effect of angiotensin converting enzyme inhibition may be due either to reduced efferent arteriolar resistance leading to diminished glomerular capillary hydraulic pressure or to enhanced intrinsic selectivity of the glomerular barrier wall, or to both. The slow and gradual reduction in microalbuminuria observed during angiotensin converting enzyme inhibition in this and other studies ${ }^{41}$ suggests a progressive reduction in the permeability of the glomerular barrier to protein. In diabetic rats converting enzyme inhibition prevents the development of albuminuria and restricts mesangial volume expansion and focal glomerulosclerosis. ${ }^{2345}$ This effect was associated with a reduction of the raised intraglomerular pressure, but in another model of experimental chronic renal disease inhibition of angiotensin II attenuated the accumulation of macromolecules in the mesangium independently of changes in intraglomerular pressure. ${ }^{46}$ Inhibition of glomerular basal membrane thickening with converting enzyme inhibition in diabetic rats has also been described. ${ }^{4}$

Morelli et al have studied the sieving profile of neutral dextran during angiotensin converting enzyme 
inhibition (enalapril) in 16 normotensive insulin dependent diabetic patients with urinary albumin excretion exceeding $50 \mu \mathrm{g} / \mathrm{min} .{ }^{+\infty}$ Angiotensin converting enzyme inhibition for 90 days significantly reduced the fractional dextran clearance and systemic blood pressure. Using a heteroporous model of the glomerular barrier and assuming either slightly reduced or unchanged transglomerular pressure, Morelli et al suggested that inhibiting converting enzyme enhances barrier size selectivity. The potential impact of angiotensin converting enzyme inhibition on charge selective properties remains to be elucidated.

Morphometric studies have shown a strong relation between mesangial expansion and the clinical manifestations of diabetic nephropathy $y^{+4}$ and an inverse correlation between the glomerular filtration rate and the glomerular filtration surface..$^{50} \mathrm{~A}$ recent morphometric study found that insulin dependent diabetic patients with microalbuminuria and hypertension or reduced creatinine clearance, or both, have established abnormalities of the glomerular structure, including fractional mesangial expansion. ${ }^{5}$ This clearly indicates that microalbuminuria in association with other signs of renal dysfunction can be a marker of diabetic glomerulopathy. The authors, however, also reported that microalbuminuria without these functional abnormalities is not a marker of underlying glomerular lesions ${ }^{51}$ and so must be regarded as a predictor of the later development of diabetic nephropathy as originally suggested. ${ }^{9.12}$

At baseline all patients in our study were normotensive and had a normal or slightly increased glomerular filtration rate. The suggestion that the development of clinical, overt diabetic nephropathy is a valid scientific end point is supported by the five to eight years' follow up of our prospective trials of 50 patients randomised to intensified treatment with insulin pumps or unchanged conventional insulin treatment. ${ }^{20} \mathrm{~A}$ significant reduction in the glomerular filtration rate 3.0 $\mathrm{ml} / \mathrm{min} /$ year) was found in those patients who developed clinical nephropathy defined as in this study, whereas the glomerular filtration rate remained normal or supranormal for at least five to eight years in those who did not progress to diabetic nephropathy. ${ }^{20}$ In this study the rate of decline in the glomerular filtration rate was $4.0 \mathrm{ml} / \mathrm{min} /$ year in patients developing diabetic nephropathy and $0.9 \mathrm{ml} / \mathrm{min} /$ year in patients not developing overt albuminuria.

\section{Conclusion}

We conclude that angiotensin converting enzyme inhibition postpones the development of diabetic nephropathy in normotensive insulin dependent diabetic patients with persistent microalbuminuria. Longer follow up, however, is mandatory to see if this will result in preservation of the normal glomerular filtration rate and improved survival without severe side effects before angiotensin converting enzyme inhibition can be advocated in these patients.

This study was supported by grants from the Danish Medical Research Foundation and the Danish Diabetes Association.

1 Andersen AR, ChristiansenJS, Andersen JK, Kreiner S, Deckert T. Diabetic nephropathy in type 1 (insulin dependent) diabetes: an epidemiological study. Diabetologia 1978:14:363-70.

2 Parving H-H, Smidt UM, Friisberg B, Bonnevie-Nielsen V, Andersen AR. A prospective study of glomerular filtration rate and arterial blood pressure in insulin dependent diabetics with diabetic nephropathy. Diabetologia 1981;20:457-61.

3 Borch-Johnsen K, Andersen PK, Deckert T. The effect of proteinuria on relative mortality in type 1 (insulin-dependent) diabetes mellitus. Diabetologia 1985;28:590-6.

4 Mogensen CE. Long-term antihypertensive treatment inhibiting progression of diabetic nephropathy. BMF 1982;285:685-8

5 Parving $\mathrm{H} \cdot \mathrm{H}$, Andersen AR, Smith U, Svendsen PA. Early aggressive mtihypertensive treatment reduces rate of decline in kidney function in diabetic nephropathy. Lancet 1983;1:1175-9.

6 Parving $\mathrm{H}-\mathrm{H}$, Andersen AR, Smidt U, Hommel E, Mathiesen ER. Svendsen PAa. Antihypertensive treatment postpones end stage renal failure in diabetic nephropathr. B.117 1987;294:1+13-7.

7 Mathiesen ER, Borch-Johnsen K, Jensen DV, Deckert T. Antihypertensive treatment improves survival in patients with insulin dependent diabetes treatment improves survival in patients with insulin
mellitus and nephropaths. Diabetologia 1989;32:884-6.

8 Parving H-H. Hommel E. Prognesis in diabetic nephropathy. BMJ 1989;299: 230-3.

9 Parving H-H, Oxenboll B, Svendsen PAa, Christiansen JS, Andersen AR. Early detection of patients at risk of developing diabetic nephropathy: longitudinal study of urinary albumin excretion. Acta Endocrinol (Copenh) 1982;100:550-5

10 Viberti GC, Hill RD, Jarrett RJ, Argyropoulos A, Mahmud U, Keen H. Microalbuminuria as a predictor of clinical nephropathy in insulindependent diabetes mellitus. Lancet 1982;1:1430-2.

11 Mogensen CE, Christensen CK. Predicting diahetic nephropathy in insulin dependent patients. N Engl F Med 1984;311:89-93.

12 Mathiesen ER, Oxenboll B, Johansen K, Svendsen PAa, Deckert T Incipient nephropathy in type 1 (insulin-dependent) diabetes. Diabetologic 1984;26:406-10.

13 Mogensen CE, Chachati A, Christensen CK. Deckert T, Hommel E, Kastrup $\mathrm{J}$, et al. Microalbuminuria, an early marker of renal involvement in diabetes. Uremia Investigation 1986;9(2):85-95.

14 Parving H-H, Hommel E, Mathiesen ER, Skot P, Edsberg B, Bahnsen M, et al. Prevalence of microalbuminuria, arterial hypertension, retinopathy and neuropathy in insulin-dependent diabetic patients. BMF 1988;296: $156-60$.

15 Niazy S, Feldt-Rasmussen B, Deckert T. Microalbuminuria in insulin dependent diabetics: prevalence and practical consequences. Diabctic dependent diabetics: preval
Complications 1987;1:76-80.

16 Mathiesen ER, Ronn B, Jensen T, Storm B, Deckert T. The relationship between blood pressure and urinary albumin excretion in the developmen of microalbuminuria. Diabetes 1990;39:245-9.

17 Norgărd K, Storm B, Graae $M$, Feldt-Rasmussen B. Elcvated albumin excretion and retinal changes in children with type 1 diabetes are related to long-term poor metabolic control. Diabetic Med 1990;6:325-8.

18 Feldt-Rasmussen B, Mathiesen ER, Deckert $T$. Effect of two years of stric metabolic control on the progression of incipient nephropathy in insulin dependent diabetes. Lancel 1986;1:1300-4.

19 Ronn B, Mathiesen ER, Vang L, Lorup B, Deckert T. Evaluation of insulin pump treatment under routine conditions. Diabetes Res Clin Pract 1987;3:191-6.

20 Feldt-Rasmussen B, Mathiesen ER, Jensen T, Lauritzen T, Deckert T. Effect of improved metabolic control on loss of kidney function in type 1 (insulindependent) diabetic patients: an update of the Steno studies. Diabetologia 1991:34:164-70.

21 Mathiesen ER, Saurbrey N, Hommel E, Parving H-H. Prevalence of microalbuminuria in chidren with type 1 (insulin-dependent) diabetes microalbuminuria in chidren with is

22 Andersen S, Rennke HG, Brenner BM. Therapeutic advantage of converting enzyme inhibitors in arresting progressive renal disease associated with enzyme inhibitors in arresting progressive renal disease associa
systemic hypertension in the rat. $\mathcal{F}$ Clin Invest 1986;77:1993-2000.

23 Zatz R, Dunn BR, Meyer TW, Anderson S, Rennke HG, Brenner B. Prevention of diabetic glomerulopathy by pharmacological amelioration of

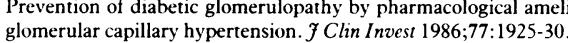

24 Hostetter TH, Rennke HG, Brenner BM. The case for intrarenal hypertension in the initiation and progression of diabetic and other glomerulopathies Am f Med 1982;72:375-80

25 Parving H-H, Viberti GC, Keen H, Christiansen JS, Lassen NA. Hemodynamic factors in the genesis of diabetic microangiopathy. Metabolism 1983;32:943-9.

26 Hommel E, Mathiesen ER, Edsberg B, Bahnsen M, Parving H-H. Acute reduction of arterial blood pressure reduces urinary albumin excretion in type 1 (insulin-dependent) diabetic patients with incipient nephropathy. Diabetologia 1986;29:211-5.

27 Parving $\mathrm{H}-\mathrm{H}$, Hommel E, Smidt UM. Protection of kidney function and decrease of albuminuria by captopril in insulin dependent diabetics with nephropathy. $B M \mathcal{F}$ 1988;297:1086-91

28 Tochikubo $\mathrm{O}$, Minamisawa K, Miyajima E, Ishii M, Yanaga Y. A new compact 24-hour indirect blood pressure recorder and its clinical application. Ipn Heart f 1988;29:257-69.

29 Christiansen C, Orskov H. Rapid screening PEG radioimmunoassay for quantification of pathological microalbuminuria. Diabetic Nephropathy quantification

30 Feldt-Rasmussen B, Mathiesen ER. Variability of urinary albumin excretion in incipient nephropathy. Diabetic Nephropathy 1984;3:101-3.

31 Parving H-H, Rasmussen SM. Transcapillary escape rate of albumin and plasma volume in short- and long-term juvenile diabetics. Scan 7 Clin Lab Invest 1973;32:81-7.

32 Brøchner-Mortensen J, Giese J, Rossing N. Renal insulin clearance versu total plasma clearance of 51Cr-EDTA. Scand F Clin Lab Invest 1969;26: $5-11$.

33 Ladegärd-Pedersen $\mathrm{HJ}$, Engel $\mathrm{HC}$. A comparison of the distribution volume of insulin and 51Cr EDTA in man and nephrectomized dogs. Scand $\mathcal{F}$ Clin Lab Invest 1972;30;267-70.

34 Hommel E, Mathiesen ER, Giese J, Nielsen MD, Schutten HJ, Parving H-H. On the pathogenesis of arterial blood pressure elevation in the course of diabetic nephropathy. Scan F Clin Lab Invest 1989;49:537-44

35 Morstensen HB. Quantitative determination of haemoglobin $A_{1 .}$ by thin-layer isoelectric focusing. $\mathcal{F}$ Chromatogr 1980;182:325-33.

36 Giese J, Damkjær Nielsen $M$, Kappelgård AM. Concentrations of active and inactive renin in human plasma: concepts and methodology. In: Samibh $M P$, ed. Heterogeneity of renin and renin-substrate. Amsterdam: Elsevier, 1981:205-13.

37 Rasmussen S, Damkjær Nielsen M, Giese J. Captopril combined with thiazide lowers renin substrate concentration: implications for methodology in renin assavs. Clin Sci 1981;60:590-3.

38 Kappelgărd AM, Damkjær Nielsen M, Giese J. Measurement of angiotensin Il in human plasma: technical modifications and practical experience. in human plasma: technical
Clin Chim Acta 1976;67:299-306.

39 Maroni BJ, Steinman TI, Mitch WE. A method for estimating nitrogen intake of patients with chronic renal failure. Kidney Int 1985;27:58-65.

to Isaksson B. Urinary nitrogen output as a validity test in dietary survey Am F Clin Nutr 1982;33:4-5.

41 Marre M, Chatellier G, Leblanc H, Guyene TT, Menard J, Passa P. 
Prevention of diabetic nephropathy with enalapril in normotensive diabetics with microalbuminuria. B.117 1988;297:1092-5.

42 Viberti GC, Pickup JC, Jarett RJ, Keen H. Effects of control of blood glucose on urinary excretion of albumin and heta ${ }_{2}$-microglobulin in insulin dependent diabetes. N Engl F Med 1979;300:638-41.

43 Cohen D, Dodds R, Viberti GC. Effect of protein restriction in insulin dependent diabetics at risk of nephropathy. B.MF 1987;294:795-8.

44 Mathiesen ER, Hommel E, Olsen UB, Parving $\mathrm{H}-\mathrm{H}$. Elevated urinary prostaglandins and the effect of indomethacin on kidney function in incipient diabetic nephropathy. Diabetic Med 1988:5:145-9.

45 Anderson S, Rennke HG, Garcia DL., Brenner B. Short and long term effects of antihypertensive therapy in the diabetic rat. Kidney Int 1989:36:526-36.

Fogo A, Yohida Y, (Glick AD, Homma T, Ichikawa J. Serial micropuncture analysis of glomerular function in two rat models of glomerular sclerosis. 7 Clin Invest 1988:82:322-30.

47 Cooper ME, Allen TJ, Macmillan PA, Clarke BE, Jerums G, Doyle AE.
Enalapril retards glomerular basement thickening and albuminuria in the diabetic rat. Diabetologia 1989;32:326-8.

48 Morelli E, Loon N, Meyer T, Peters W, Meyers BD. Effects of convertingenzyme inhibition in diabetic glomerulopathy. Diabetes 1990;39:76-82.

49 Mauer SM, Steffes MW, Ellis EN, Sutherland DER, Brown DM, Goetz FC. Structural-functional relationships in diabetic nephropathy. $\mathcal{F}$ Clin Invesi 1984;74:1143-55.

50 Østerby R, Parving H-H, Nyberg G, Hommel E, Jørgensen HE, Løkkegård $\mathrm{H}$, et al. A strong correlation between glomerular filtration rate and filtration surface in diabetic nephropathy. Diabetologia 1988;31:265-70.

51 Chavers BM, Bilous RW, Ellis EN, Steffes MW, Mauer SM. Glomerular lesions and urinary albumin excretion in type 1 diabetes without overt proteinuria. N Engl f Med 1989;320:966-70.

(Accepted 10 Mav 199I)
Department of Diagnostic Radiology, Turku University Hospital, SF20520 Turku, Finland Timo Kallio, MD, junio hospital medical officer

BMf 1991;303:87-9

\title{
Assessment of blood echogenicity as an alternative measure to erythrocyte sedimentation rate
}

\author{
Timo Kallio
}

\begin{abstract}
Objective-To determine the relation between erythrocyte sedimentation rate and blood echogenicity and whether measurement of erythrocyte sedimentation rate could be replaced by measurement of blood echogenicity in monitoring acute phase reactions.

Design-Simultaneous measurement of echogenicity of flowing blood and erythrocyte sedimentation rate in blood samples and comparison of results.
\end{abstract}

Setting - A radiological department in a university hospital.

Subjects -83 patients with a suspected venous thrombosis and $\mathbf{3 6}$ healthy volunteers.

Main outcome measures-Correlations between the erythrocyte sedimentation rate, packed cell volume, and echogenicity of flowing blood.

Results-Blood echogenicity correlated poorly with the packed cell volume, but strongly correlated with the erythrocyte sedimentation rate (when the packed cell volume was within reference limits) (correlation coefficient $=0 \cdot 73$ ). Blood samples with a greatly raised erythrocyte sedimentation rate were highly echogenic. Only one of the $\mathbf{3 0}$ samples with an erythrocyte sedimentation rate below $10 \mathrm{~mm}$ in first hour had a higher echogenicity than the least echogenic sample of the 19 with a sedimentation rate above $30 \mathrm{~mm}$ in first hour.

Conclusions-Echogenicity of flowing blood correlates with the erythrocyte sedimentation rate and its measurement may compete with conventional methods for evaluating the long term changes in acute phase reactions. Also, it has the added advantage that non-invasive in vivo measurements of blood echogenicity may become possible.

\section{Introduction}

The plasma concentration of macromolecules increases during the acute phase response to infection. This enhances the aggregation of red blood cells, raising the amount of sedimentation. ${ }^{1}$ The rate of erythrocyte sedimentation is used as a universal routine screening test and a measure of the progress of some inflammatory diseases. The reliability of the test is hampered by its dependence on packed cell volume and lack of specificity; several methods have been developed to overcome these disadvantages, but none has gained wide use. ${ }^{23}$

Erythrocyte aggregation causes appreciable variability in ultrasonic scattering by blood. ${ }^{+-6}$ The echogenicity of erythrocytes is related to the size of the aggregates. Alanen and I have developed a method for measuring the echogenicity of flowing blood in vitro. ${ }^{8}$ In the present study I examined the relation between the erythrocyte sedimentation rate and blood echogenicity.

\section{Materials and methods}

By a standard method (with a Vacutainer, Becton Dickinson, France) $15 \mathrm{ml}$ of venous blood was drawn from each of 139 subjects into heparinised evacuated containers. Subjects comprised 101 patients with a presumptive diagnosis of venous thrombosis in the leg and 38 healthy volunteers. The blood was stored at room temperature. All of the tests were completed within two hours.

The erythrocyte sedimentation rate of the samples was measured by the Guest method (with a Dispette, Guest Medical and Dental Products, Switzerland), which correlates well $(r>0.9)$ with the Westergren method. ${ }^{9}$ The packed cell volume of each sample was also determined.

The echogenicity of the undiluted samples was measured by a computerised method ${ }^{8}$ : a calibrated peristaltic pump established a flow of $3.8 \mathrm{~mm} / \mathrm{s}$ in a measuring chamber with a diameter of $5 \mathrm{~mm}$, corresponding to a shear rate of $4 / \mathrm{s}$. Ultrasonic echoes were registered with a single crystal unfocused $6 \mathrm{MHz}$ transducer. Each recording lasted for four seconds and produced $20 \mathrm{~A}$-mode curves, which were digitised at $20 \mathrm{MHz}$ and transferred to the computer memory and stored on floppy discs for further analysis by integration

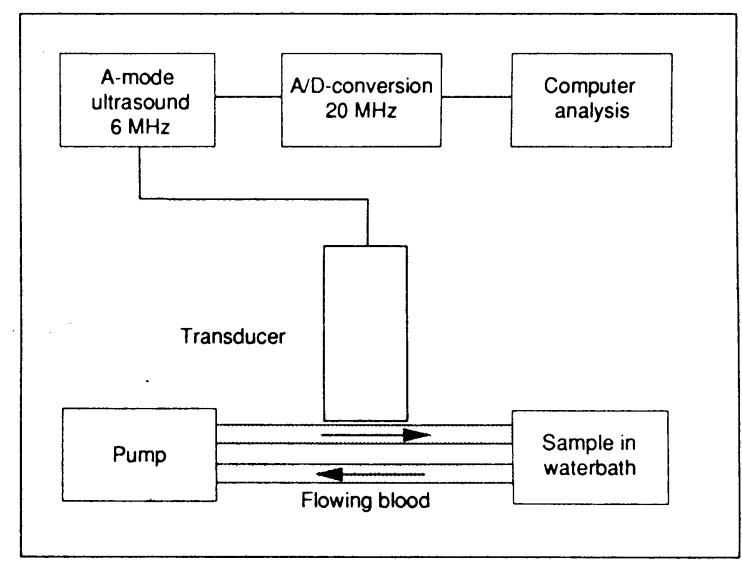

FIG 1-Ultrasonic method for measuring blood echogenicity 